and private practice in all provinces that have not enacted substantially similar privacy legislation.

NAPRA has publicly available guidelines for the protection of an individual's health-related information. ${ }^{3}$ The guidelines do not permit disclosure of any information to a third party, such as a commercial data compiler, where there is a reasonable expectation that such disclosure would identify the patient.

\section{Barbara Wells}

Executive Director

National Association of Pharmacy

Regulatory Authorities

Ottawa, Ont.

\section{References}

1. Zoutman DE, Ford BD, Bassili AR. The confidentiality of patient and physician information in pharmacy prescription records [editorial]. CMAJ 2004;170(5):815-6.

2. Radwanski G. PIPED Act case summary \#15. Ottawa: Office of the Privacy Commissioner of Canada; 2001 Oct 2 [updated 2004 Apr 1]. Available: www.privcom.gc.ca/media/an/wn_011002 _e.asp (accessed 2004 Jun 21).

3. Model guidelines for pharmacists to comply with provincial privacy legislation. Ottawa (ON): $\mathrm{Na}$ tional Association of Pharmacy Regulatory Authorities; upated 2002 Mar 21. Available: www .napra.org/docs/0/95/158/188.asp (accessed 2004 Jun 8).

DOI:10.1503/cmaj.1040772

\section{[The authors respond:]}

$\mathrm{B}^{2}$ arbara Wells disagrees with our statement that potential patient identifiers are disclosed from pharmacies located across Canada. ${ }^{1}$ We based this assertion on the findings of the office of the Alberta privacy commissioner, ${ }^{2}$ which were in turn largely based on the testimony of IMS Health; that organization reported compiling up to 37 data fields from over 4000 pharmacies across Canada. ${ }^{2}$ Furthermore, in our survey the pharmacy regulatory authorities of British Columbia, Saskatchewan, Ontario, Prince Edward Island, and Newfoundland and Labrador reported that it was permissible to sell patient birth date and sex, as well as the identity of third-party payers. ${ }^{1}$ The evidence is clear that potential patient identifiers are disclosed from Canadian pharmacies.

Our thesis is that modern computer database management allows for personal health information downloaded from pharmacies without patient names and addresses to be subsequently linked with databases that contain such information. We do not state that this linkage is occurring, only that there is a danger of it happening. We think it is best to err on the side of caution when it comes to the confidentiality of personal health information.

Wells makes hay out of our statement that we are unaware of a PIPEDA-based challenge to the selling of patient information from pharmacies. This is to be expected, given that PIPEDA only came into full force, with application to pharmacies, on Jan. 1,2004 . The primary reason, though, is that patients are unaware of the downloading practices of pharmacies, and pharmacy pamphlets do not inform patients of disclosures to data compilers. ${ }^{3,4}$

Wells contends that members of the NAPRA are mandated to protect the interests of patients and not health care providers. It should be understood by everyone that allowing pharmaceutical sales representatives to have access to physicians' prescribing histories negatively affects prescribing practices ${ }^{5}$ and is detrimental to patient health. Commercial data compilers use physicians' prescribing histories to profile physicians for the purposes of increasing drug sales, not in consideration of patient health. ${ }^{6,7}$

We recommend that NAPRA reexamine its policies and guidelines in light of the probable effects of modern technology on the confidentiality of patient and physician information held in trust in Canadian pharmacies. ${ }^{1}$ NAPRA should put the interests of patients and physicians ahead of those of the data compilation industry.

\section{Dick E. Zoutman}

B. Douglas Ford

Assil R. Bassili

Department of Pathology and Molecular

Medicine

Queen's University

Kingston, Ont.

\section{References}

1. Zoutman DE, Ford BD, Bassili AR. The confidentiality of patient and physician information in pharmacy prescription records [editorial]. CMAJ 2004;170(5):815-6.

2. Work FJ. Alberta pharmacists and pharmacies. Edmonton: Office of the Information and Privacy Commissioner; 2003.

3. The law on privacy is changing [patient information brochure]. Oshawa (ON): Lovell Drugs; 2003.

4. Privacy policy [patient information brochure]. Markham (ON): PharmAssist (Katz Group of Companies); 2003.

5. Wazana A. Physicians and the pharmaceutical industry: Is a gift ever just a gift? $7 A M A 2000$; 283:373-80.

6. Zoutman DE, Ford BD, Bassili AR. A call for the regulation of prescription data mining. CMA7 2000;163(9):1146-8.

7. Kallukaran P, Kagan J. Data mining at IMS Health: how we turned a mountain of data into a few information-rich molehills. In: Proceedings of the 24th Annual SAS Users Group International Conference; 1999 Apr 11-14; Miami Beach, Fla. Available: www2.sas.com/proceedings/sugi24 /Dataware/p127-24.pdf (accessed 2004 Aug 10).

DOI:10.1503/cmaj.1041052

\section{Correction}

$T$ he Health and Drug Alerts article on Zelnorm ${ }^{1}$ contained 2 errors. First, the complete description for Zelnorm is "the serotonin 5-HT4 receptor partial agonist, tegaserod (Zelnorm)." Second, the approximate number of people who will have very serious diarrhea is 1 in 2500 (or $0.04 \%$ ), not 1 in 250 (or $0.4 \%$ ) as stated in the article.

\section{Reference}

1. Wooltorton E. Tegaserod (Zelnorm) for irritable bowel syndrome: reports of serious diarrhea and intestinal ischemia. CMAf 2004;170(13): 1908.

DOI:10.1503/cmaj.1041458 